\title{
Biodiversity and population fluctuations of parasitoids of the white peach scale, Pseudaulacaspis pentagona (Targioni- Tozzetti) (Hemiptera: Diaspididae), in kiwifruit orchards in Northern Iran
}

\author{
A.H. Toorani ${ }^{1 *}$, H. Abbasipour ${ }^{2}$ and L. Dehghan-Dehnavi ${ }^{3}$
}

Summary The white peach scale, Pseudaulacaspis pentagona Targioni-Tozzetti (Hemiptera: Diaspididae), is one of the most important and destructive polyphagous pests of the Rosaceae family trees. Population fluctuations and biodiversity of the hymenopteran parasitoid species associated with the pest were studied in six kiwi orchards in Iran, during one-year period. Parasitoid species abundance, species diversity indices and evenness indices were calculated. Most of the parasitoid species were dominant or eudominant. Based on the alpha diversity indices, the Najarkola region had high diversity and the Kharatkola region had low diversity. The Paeendasteh region (based on Simpson's Diversity on Camargo evenness indices) and the Samnakola region (based on the modified Nee, and on Smith and Wilson evenness indices) were less uniform. Among the recorded parasitoids, Encarsia berlesei Howard (Hymenoptera: Aphelinidae), followed by Aphytis proclia Walker (Hymenoptera: Aphelinidae), had the highest population in all orchards.

Additional keywords: Pseudaulacaspis pentagona, parasitoids, diversity, evenness index, species abundance, species richness

\section{Introduction}

The white peach scale, Pseudaulacaspis pentagona (Targioni-Tozzetti) (Hemiptera: Diaspididae), is the most important pest of kiwi fruit trees in Iran and other countries (Miller and Davidson, 2005; Toorani, 2017), attacking branches and twigs. The scale is most often seen in large numbers on the bottom of stems. The scale feeds on plant sap, and infestation causes leaves to yellow or defoliation and branches to dry. Fruit size may be reduced and premature drop is likely. Heavy infestations can result in stunting and the death of branches and dieback (Ezzat and Nada, 1986).

The families Aphelinidae and Encyrtidae are the most successful groups of Chalcidoidea, Hymenoptera used in the biolog-

\footnotetext{
1,2 MSc gratuated student and professor, Department of Plant Protection, Faculty of Agricultural Sciences, Shahed University, Tehran, Iran.

3 Young Researchers and Elite Club, Yard Branch, Islamic Azad University, Yarzd, Iran.

* Corresponding author: Amirhoseyn.toorani@gmail.com
}

ical control of pest scale insects (Guerrieri and Noyes, 2000). Regarding reports on parasitoids of the white peach scale, the solitary endoparasitoid Encarsia berlesei Howard (Hym.: Aphelinidae) is considered to be the most effective species among the white peach scale natural enemies (Collins and Whitecomb, 1975), whose origin, like the white peach scale, is East Asia. Aphytis chrysomphali (Mercet) (Hym.: Aphelinidae) has been reported on the white peach scale in apricot and cherry trees from Shanghai, China (Invasive Species Compendium, 2016). In Iran, another three parasitoid species have been recorded, Aphytis proclia Walker (Hym.: Aphelinidae) (Modarres Awal, 1997), Ablerus perspeciosus Girault (Hym.: Aphelinidae) (Jamalomidi et al., 2012) and Teleterebratus perversus Compere and Zinna (Hym.: Encyrtidae) (Toorani, 2017).

Protecting biodiversity of taxonomic groups for which there are no available data on their existence or role in the ecosystem, is an important subject (Gaston, 1991). Alpha (a) diversity is intra (within) - habitat diversity. The species diversity is the main level 
of alpha diversity in the sense of the number of existing species and their abundance (evenness) in a geographical region, which increases with increasing number of existing species.

The present study was carried out to provide information on the species composition, diversity, evenness and population fluctuations of the hymenopterous parasitoids associated with the white peach scale, P. pentagona, in kiwi orchards in Iran.

\section{Materials and methods}

\section{Experimental set up and data collection}

This study was carried out in the kiwi orchards of Qaemshahr city, Mazandaran province of Iran. The laboratory experiments were carried out in the laboratory of Entomology and Insectarium of the Faculty of Agriculture Sciences of Shahed University of Tehran. In order to study the population fluctuations of parasitoid species associated with the pest under natural conditions on kiwi trees, six orchards, which had a history of pest infestation in previous years and had not received pesticides, at Qaemshahr and Mollakola areas ( $36^{\circ} 35^{\prime} 44.20^{\prime \prime} \mathrm{N}, 52^{\circ} 46^{\prime}$ $35.09^{\prime \prime} \mathrm{E}$ and $-10.23 \mathrm{~m}$ a.s.l); Borjekheyl ( $36^{\circ}$ $36^{\prime} 3.43 \mathrm{~N}, 52^{\circ} 46^{\prime} 23.94 \mathrm{E}$ and $-13.28 \mathrm{~m}$ a.s.l); Kharatkola ( $36^{\circ} 33^{\prime} 1.07^{\prime \prime} \mathrm{N}, 52^{\circ} 50^{\prime} 12.08^{\prime \prime}$ $\mathrm{E}$ and $-4.23 \mathrm{~m}$ a.s.l); Paeendasteh ( $36^{\circ} 36^{\prime}$ $39.59^{\prime \prime} \mathrm{N}, 52^{\circ} 47^{\prime} 47.39^{\prime \prime} \mathrm{E}$ and $-11.63 \mathrm{~m}$ a.s.l); Samnakola ( $36^{\circ} 32^{\prime} 51.40^{\prime \prime} \mathrm{N}, 52^{\circ} 48^{\prime} 34.03^{\prime \prime} \mathrm{E}$ and $-0.21 \mathrm{~m}$ a.s.l and Najarkola ( $36^{\circ} 33^{\prime} 20.26$ $\mathrm{N}, 52^{\circ} 48^{\prime} 55.42 \mathrm{E}$ and $-3.99 \mathrm{~m}$ a.s.l) were selected for sampling.

Sampling started on April 30, 2015, and ended on April 29, 2016. The samples were collected biweekly until January 22, 2016, and then monthly. Ten trees were randomly selected and marked on each date. Four infested branches were cut to a length of 10 $\mathrm{cm}$ each and placed in plastic glasses $(5 \mathrm{~cm}$ diameter and $10 \mathrm{~cm}$ height), closed with a net cloth. Emerged parasitoids were collected and stored in $75 \%$ ethanol. In addition, on some sampling dates, a large number of infested branches of kiwi trees, were placed in cardboard boxes $(50 \times 20 \times 45 \mathrm{~cm})$ bearing six test tubes on each side of the box. The boxes were kept under natural conditions and emerging parasitoids were collected in the test tubes at 10-day intervals and stored in alcohol. The collected specimens were primarily identified and then, were sent for confirmation of identification, to Dr Andrew Polaszek, Department of Life Sciences, Natural History Museum.

\section{Estimation of parasitoid species compo- sition, abundance, diversity, evenness and population fluctuations}

The data from the aforementioned six areas were used to calculate species diversity during 2015-2016. After identifying and counting the captured specimens, the dominant structure of species composition was evaluated using the method of Headman (Weigmann, 1973). In this method, the species, which their abundances are more than $30 \%$ of the society are identified as eudominant species, $10-30 \%$ as dominant, $5-10 \%$ as subdominant, $1-5 \%$ as rare, and less than $1 \%$ as sub-rare species.

Species diversity and relative abundance of the parasitoid species of $P$. pentagona were calculated in the different ecosystems of the Mazandaran province, using the Ecological Methodology software version 7.2. Based on the number of individuals per parasitoid species in each region, indicators of species diversity (number of species in a community, diversity in a region) and species evenness (number of individuals for each species, abundance and proportion of individuals of each species) were calculated.

Alpha species diversity was estimated using the Indices Shannon-Wiener (Shannon and Weaver, 1949) as the most common indicator to measure biodiversity and sensitive to the abundance of rare species in the community, Simpson's (Simpson, 1949) as a sensitive index to changes in more abundant species, and Brillouin (Pielou, 1969) as most appropriate for cases in which data are related to limited collections.

To estimate species equitability or even- 
ness, the Smith and Wilson (Smith and Wilson 1996), modified Nee (Nee et al. 1992), Simpson (Simpson 1949) and Camargo (Camargo 1992) indices were used.

\section{Results}

\section{Parasitoid species composition}

In total, six parasitoid species were recorded in the study areas i.e. Encarsia perniciosi Tower (Hymenoptera: Aphelinidae), A. chrysomphali, E. berlesei, A. perspeciosus, A. proclia, T. perversus. Results for the species composition in each region are shown in Table 1.

\section{Parasitoid species abundance}

Encarcia perniciosi and A. chrysomphali had the highest abundance percent at Samnakola and Najarkola orchards, while E. berlesei and $A$. proclia had the highest abundance percent at Mollakola orchard. The abundance of E. berlesei species at Kharatkola orchard was (83.66\%). The abundance of $A$. perspeciosus was zero at Mollakola, Borjekheyl and Kharatkola orchards (Table 1). According to Headman's categorization on species dominance proportion in the society (Weigmann, 1973), most of the six collected were eudominant or dominant (Table 1).

\section{Alpha diversity}

According to all indices, the parasitoid species diversity was higher in all regions compared to the Kharatkola region (Figure 1).

\section{Species evenness}

Based on the results obtained from the Camargo and Simpson eveness indices (Figure 2), the Paeendasteh region was the least uniform whereas according to the modified Nee index and the Smith and Wilson index, the Samnakola region were the least uniform (Figure 2). Based on diversity studies, the more uniform the species diversity is, the more diversity exists in the environment.

\section{Population fluctuation of parasitoids}

Figure 3 shows that the population of the parasitoids of the white peach scale dif-

Table 1. Relative abundance (\%) and dominance proportion of parasitoids of the white peach scale, Pseudaulacaspis pentagona, in kiwi orchards in six regions of northern Iran during 2015-2016.

\begin{tabular}{l|c|c|c|c|c|c}
\hline Species & Samnakola & Najarkola & Mollakola & Borjekheyl & Kharatkola & Paeendasteh \\
\hline Encarsia & 30.9 & 27.09 & 6.68 & 6.08 & 0 & 2.55 \\
perniciosi & Eudominant & Dominant & Subdominant & Subdominant & Subrare & Rare \\
& $(233)$ & $(207)$ & $(49)$ & $(54)$ & $(0)$ & $(9)$ \\
Aphytis & 25.9 & 52.9 & 7.77 & 22.07 & 0 & 36.07 \\
chrysomphali & Dominant & Dominant & Subdominant & Dominant & Subrare & Eudominant \\
& $(196)$ & $(176)$ & $(57)$ & $(196)$ & $(0)$ & $(127)$ \\
Encarsia & 19.8 & 19.63 & 45.42 & 31.64 & 83.66 & 47.72 \\
berlesei & Dominant & Dominant & Eudominant & Eudominant & Eudominant & Eudominant \\
& $(149)$ & $(150)$ & $(333)$ & $(281)$ & $(128)$ & $(168)$ \\
Ablerus & 17.1 & 19.37 & 0 & 0 & 0 & 9.94 \\
perspeciosus & Dominant & Dominant & Subrare & Subrare & Subrare & Subdominant \\
& $(129)$ & $(148)$ & $(0)$ & $(0)$ & $(0)$ & $(35)$ \\
Aphytis & 5.7 & 8.24 & 40.10 & 40.2 & 12.41 & 1.70 \\
proclia & Subdominant & Subdominant & Eudominant & Eudominant & Dominant & Rare \\
& $(43)$ & $(63)$ & $(294)$ & $(357)$ & $(19)$ & $(6)$ \\
Teleterebratus & Subrare & Rare & Subrare & Subrare & Rare & Rare \\
perversus & $(4)$ & $(20)$ & $(0)$ & $(0)$ & $(6)$ & $(7)$ \\
\hline
\end{tabular}

Parasitoid species categorization by Headman (Weigmann, 1973) according to their dominance proportion in the society: eudominant $(>30 \%)$, dominant $(10-30 \%)$, subdominant $(5-10 \%)$, rare $(1-5 \%)$, sub-rare $(<1 \%)$.

Number in parentheses indicate the sample size. 

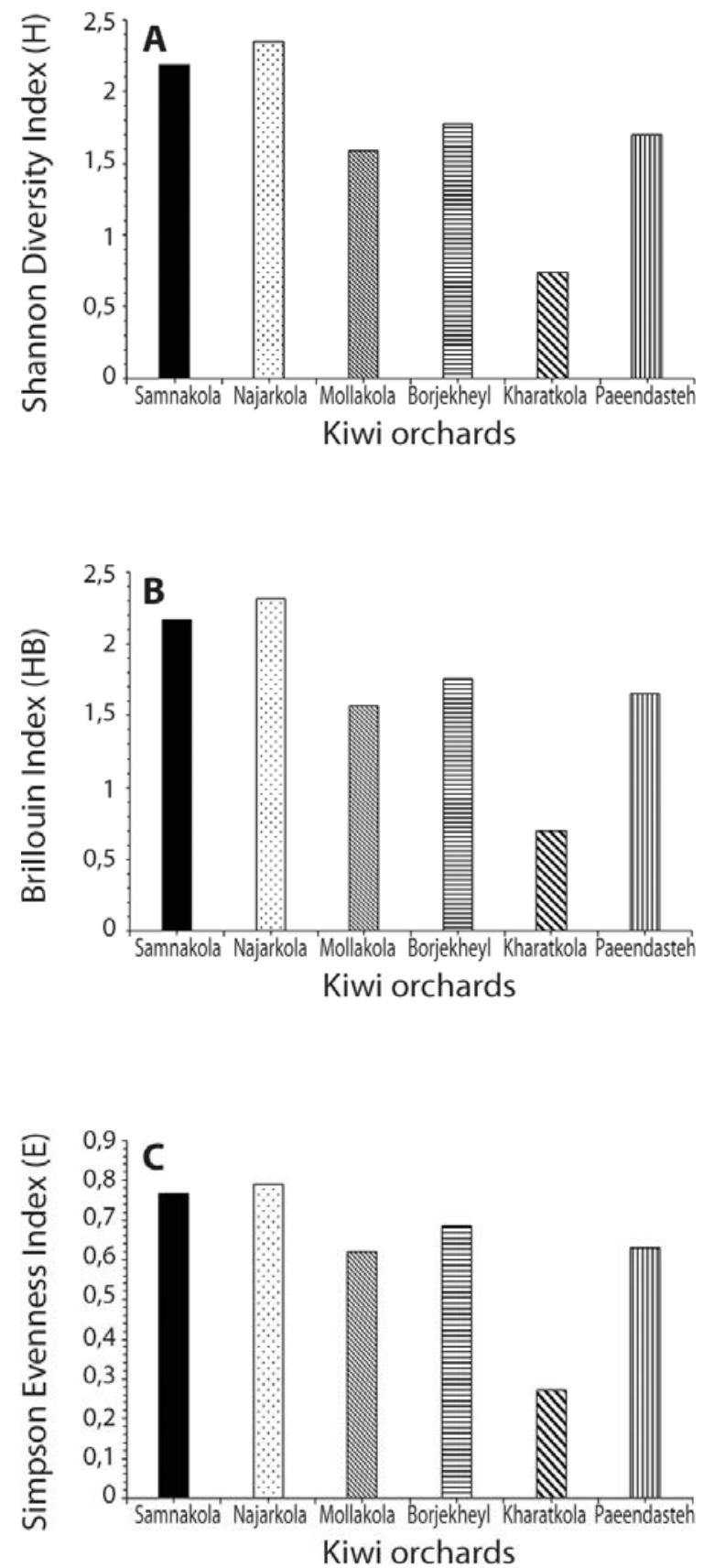

Figure 1. Alfa species diversity indices of parasitoids of the white peach scale, Pseudaulacaspis pentagona, in kiwi orchards in six regions of northern Iran during 2015-2016: A) Shannon Wiener diversity index, B) Brillouin diversity index, C) Simpson diversity index.
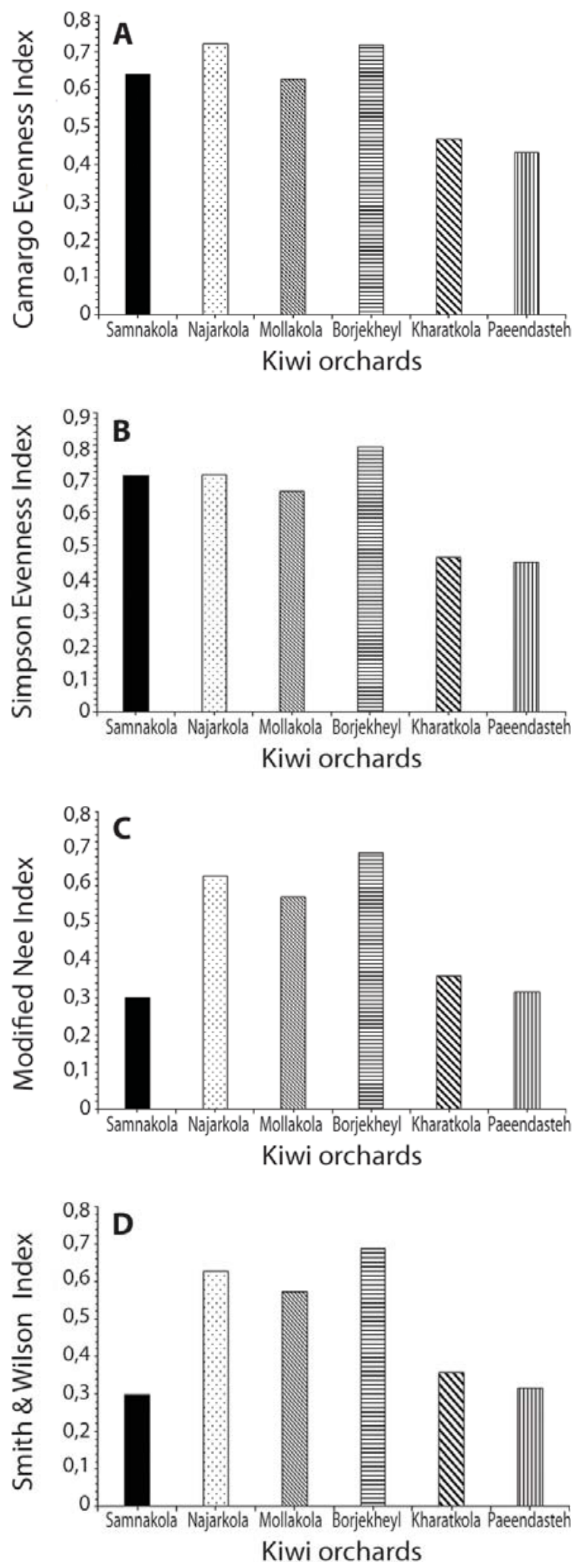

Figure 2. Species evenness indices of parasitoids of the white peach scale, Pseudaulacaspis pentagona, in kiwi orchards in six regions of northern Iran during 2015-2016: A) Camargo evenness index, B) Simpson evenness index, C) Modified Nee evenness index, D) Smith and Wilson evenness index. 


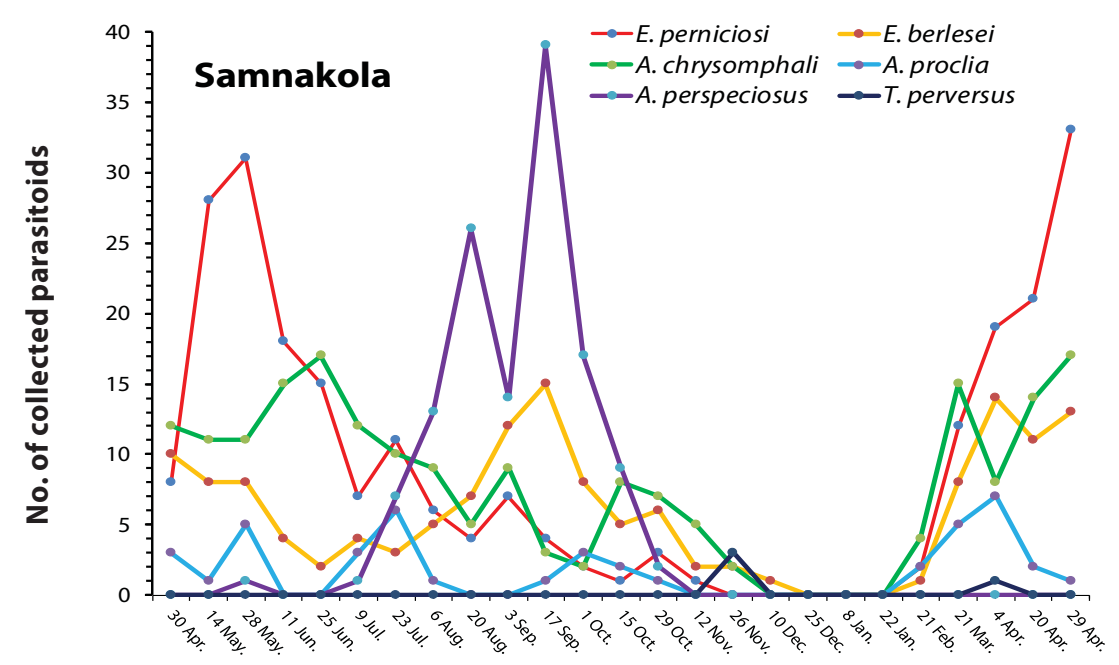

Sampling dates (2015-16)

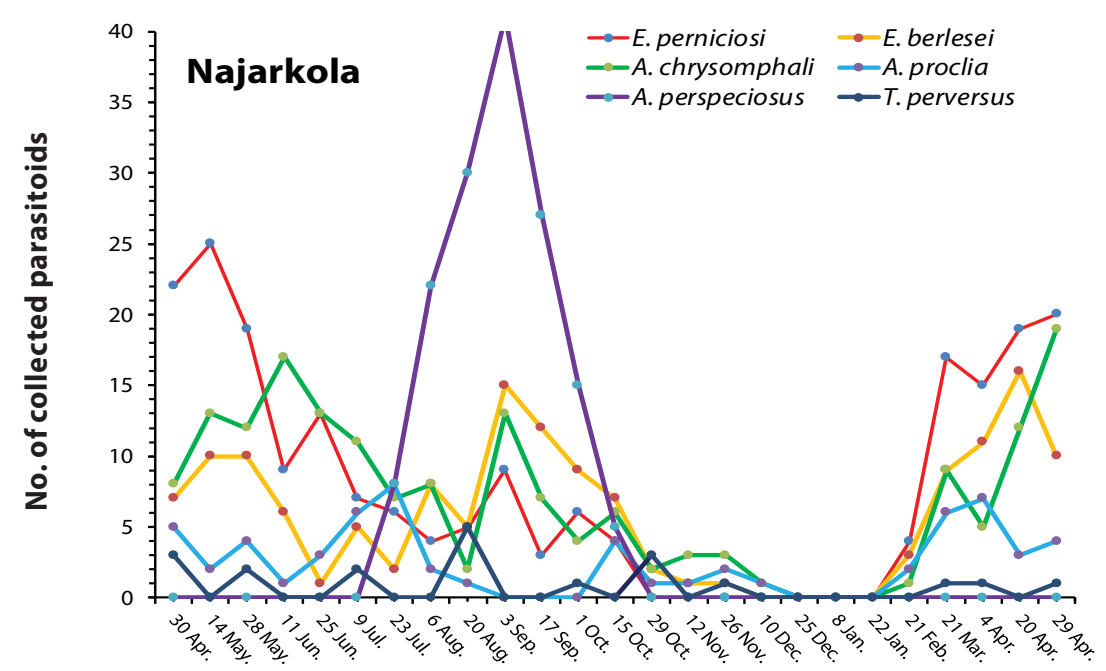

Sampling dates (2015-16)

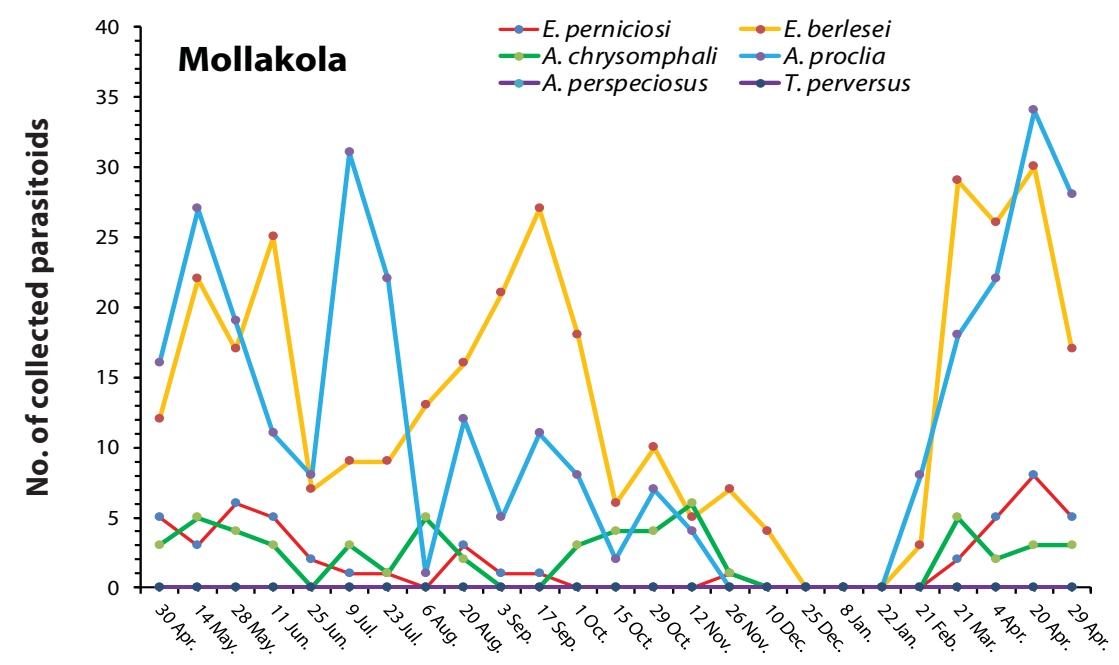

Sampling dates (2015-16) 

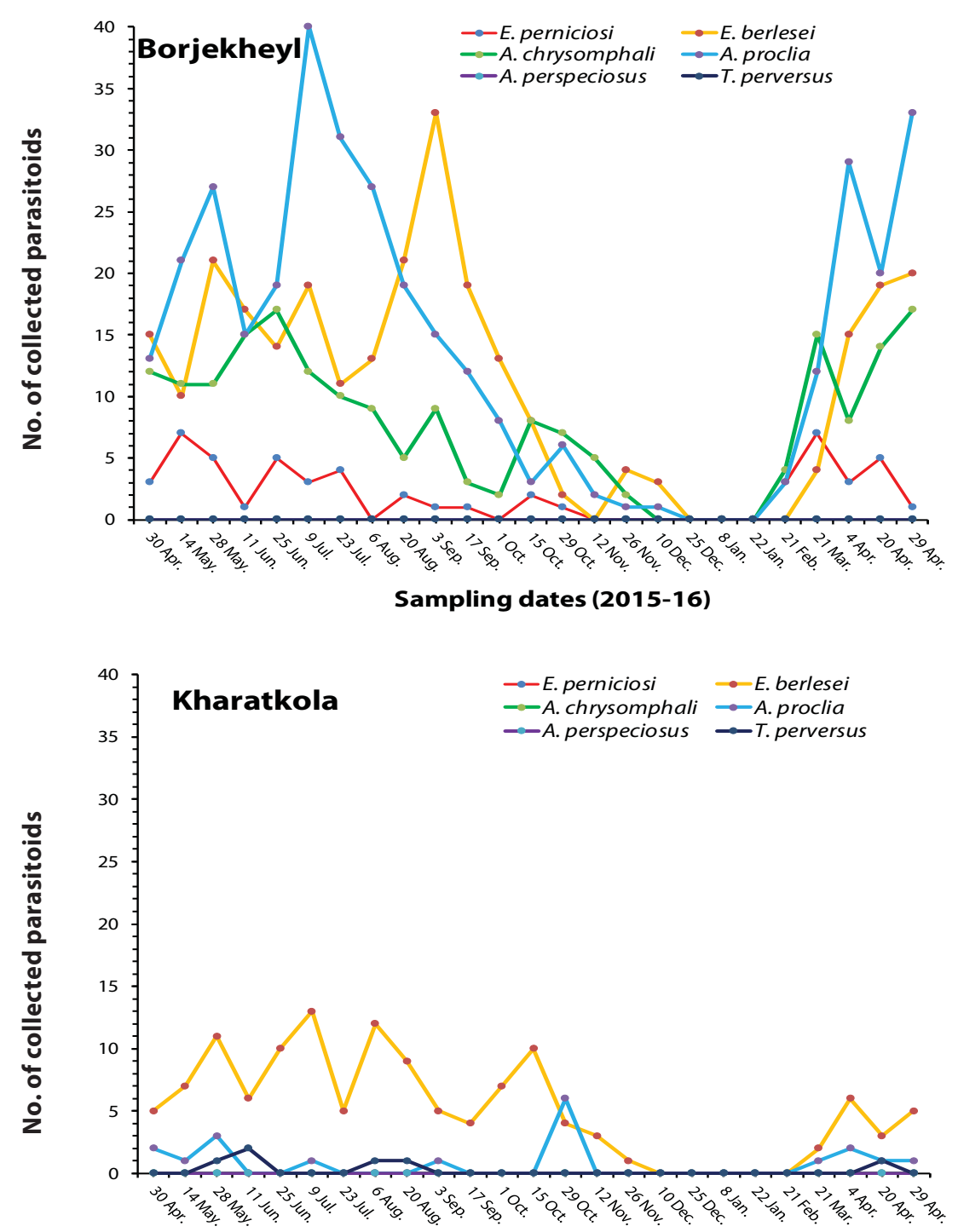

Sampling dates (2015-16)

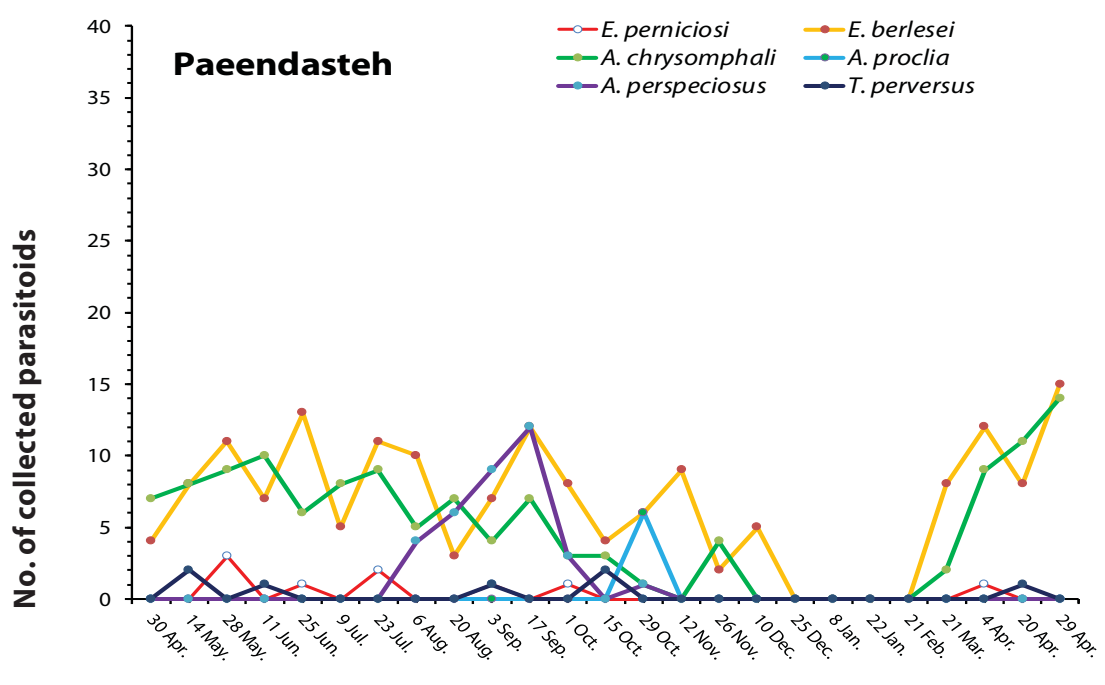

Sampling dates (2015-16)

Figure 3. Population fluctuations of different species of parasitoids of the white peach scale, Pseudaulacaspis pentagona, in kiwi orchards of northern Iran during 2015-2016.

(c) Benaki Phytopathological Institute 
fers among the studied orchards as well as on different sampling dates, reaching the lowest (zero) at the end of December - beginning of January in all orchards due to coincidence with the winter colds and overwintering of these parasitoids.

In all orchards, E. berlesei $(n=1209)$ had the highest numbers followed by $A$. proclia $(n=782)$. These two species had significant ups and downs during sampling. Ablerus perspeciosus was observed in three orchards in the areas of Samankola, Najarkola and Paeendasteh, showing 1-2 peaks from August to October. Encarsia perniciosi and A. chrysomphali were collected from all the studied orchards, except for the one in Kharatkola, and were present from spring to autumn with their population reducing until reaching zero in the winter. Teleterebratus perversus was recorded in small numbers from spring to autumn at the orchards of the areas Najarkola, Kharatkola and Paeendasteh.

\section{Discussion}

To our knowledge this is the first record on the biodiversity and population fluctuation of the parasitoid species of the white peach scale in kiwi orchards in Iran. Five out of the total six species recorded in the samples are known to parasitize P. pentagona in Iran, i.e. Encarsia berlesei Howard (Hymenoptera: Aphelinidae) (the most effective), Aphytis chrysomphali (Hymenoptera: Aphelinidae) (Invasive Species Compendium, 2016) Aphytis proclia Walker (Hymenoptera: Aphelinidae) (Modarres Awal, 1997), Ablerus perspeciosus (Jamalomidi et al., 2012) and Teleterebratus perversus (Toorani, 2017). Encarsia perniciosi has not been reported on the white peach scale in Iran.

Encarsia berlesei was the most abundant of all parasitoid species in all regions of the study. Except of the wheat peach scale, it parasitizes another 10 species of the Diaspididae family, including Aulacaspis cinnamomi Newstead, Chrysomphalus dictyospermi Morgan, Chrysomphalus obscurus Lizer y Trelles, Diaspis pentagona Fargioni, Melanaspis obscura Comstock, Nuculaspis abietis Schrank, Parlatoria pergandii Comstock, Pinnaspis minor Maskell, Pinnaspis strachani Cooley and Pinnaspis temporaria Ferris (Natural History Museum, 2016). Other hosts of A. chrysomphali include various scale species in the families of Coccidae and Diaspididae (61 species) (Natural History Museum, 2016).

Records of other host scales of E. perniciosi, A. proclia and A. perspeciosus in Iran include: E. perniciosi has been reported on Quadraspidiotus perniciosus Comstock (Modarres Awal, 1997; Ghahari et al., 2011), Aonidiella aurantii Maskell, Lepidosaphes ulmi Linnaeus, Parlatoria acalcarata McKenzie and Quadraspidiotus gigas Ferris (Heraty et al., 2007); A. proclia has been recorded on A. aurantii, Aonidiella orientalis Newstead, C. dictyospermi, and Parlatoria oleae Colvee (Modarres et al., 1997); A. perspeciosus has been found on $Q$. perniciosus Comstock (Abd-Rabou and Ghahari 2005; Aliakbar Aghadokht et al., 2010) and Aleurolobus barodensis Maskell (Hemiptera: Aleyrodidae) (Jamalomidi et al., 2012).

Differences in the parasitoid species composition, richness and abundance among the studied areas could be attributed to several factors that can affect the presence of a parasitoid in the orchard, such as the type of vegetation around the orchard, the history of chemical applications in the orchard, the area and age of the trees, the population of the host pest, as well as environmental parameters (temperature, humidity, latitude and longitude, sea level altitude) (Lotfalizadeh et al., 2014; Habibi Badrabadi et al., 2017 and Iranmanesh et al., 2017). The richer species composition and abundance of parasitoid species of the white peach scale in Samnakola, compared to the other areas, could be related to the fact that the majority of orchards in this area are kiwi trees, dating for several years. The poorer species variety and number of parasitoids in Kharatkola could be associated to the presence of only one kiwi orchard and the young age of the trees, whereas rice is the dominant cultiva- 
tion in the region.

Lower richness in the Kharatkola, Borjekheyl and Paeendasteh regions can be associated with the application of organophosphorus pesticides (such as chlorpyrifos and diazinon), whereas applications with mineral oil and botanical pesticides are related to higher richness in Samnakola, Najarkola and Mollakola (unpublished data). Nevertheless, Kyparissoudas (1987) showed that in orchards where chemical pesticides were applied, E. perniciosi wasps were not captured in pheromone traps of its host $Q$. perniciosus.

The population of parasitoid species of $P$. pentagona varied in the sampling regions. Encarsia berlesei had 4-6 population peaks on white peach scale in kiwi orchards in the present study. Bazrafshan et al. (2010) observed two peaks of the parasitism rate for the parasitoid on peach trees. Moreover, they showed that plant species has an effect on the rate of parasitism and the associated number of peaks. In our case, it is possible that the activity of parasitoids is favored by the micro-climate conditions in kiwifruit orchards (in comparison to peach orchards), where the pest is located on shoots in the shade.

According to Pedata et al. (1995), the population of $A$. proclia on white peach scale in a mulberry orchard in Campania, Italy, reached a peak in April, which is similar to the results of the present study. Seasonal abundance of Aphytis sp. had three larval and pupal peaks on white peach scale in peach trees in Dakahlia governorate, Egypt, in two successive seasons (2013-2014 and 2014-2015) (Halawa et al., 2015).

In the Hafez (1988) study, A. chrysomphali was found to be fairly abundant on A. aurantii in Citrus sinensis orchards in Alexandria, Egypt, with three peaks of activity in June, October and November.

\section{Conclusions}

In conclusion, results of the present study corroborate the existence of several hy- menopterous parasitoid species of $P$. pentagona in kiwi fruit orchards in Iran. In general, E. berlesei, A. chrysomphali and A. proclia were abundant in most of the study regions. In view of the high prevalence of these species at the peak population dates, these results, together with the data on the parasitoid population changes over the crop season, can facilitate the designing of biological control programs against the white peach scale.

We are thankful of Faculty of Agricultural Sciences, Shahed University, Tehran, Iran for having supported our research.

\section{Literature Cited}

Abd-Rabou, S. and Ghahari, H. 2005. List of hyperparasitoids of whiteflies and coccids (Homoptera) In Iran, with special study on Iranian Ablerus (Hymenoptra: Aphelinidae). Egyptian Journal of Agricultural Research, 83 (1): 311-317.

Aliakbar Aghadokht, P., Sarailoo, M.H., Yazdanian, M., Mottaki, E. and Polaszek A. 2010. New report for wasp's fauna for Iran. Proceedings of 19th Iranian Plant Protection Congress, Iranian Research Institute of Plant Protection, Tehran, 122.

Bazrafshan, B., Razmjou, J., Damavandian, M.R. and Rafiee Dastjerdi, H. 2010. Population dynamics of the white peach scale, Pseudaulacaspis pentagona and its important natural enemies in Mazandaran. M.Sc. thesis, Mohaghegh Ardabili University, Ardabil, Iran.

Camargo J.A. 1992. New diversity index for assessing structural alterations in aquatic communities. Bulletin of Environmental Contamination and Toxicology, 48 (3): p.428-434.

Collins, F.A. and Whitcomb, W.H. 1975. Natural enemies of the white peach scale, Pseudaulacaspis pentagona (Homoptera: Cooccidae), in Florida. Florida Entomologist, 54 (1): 91-95.

Ezzat, Y.M. and Nada, S.M. 1986. List of superfamily Coccoidea as known to exist in Egypt. Bollettino del Laboratorio di Entomologia Agraria, Filippo Silvestri, 43: 85-90.

Gaston, H.J. 1991. The magnitude of global insect species richness. Conservation Biology, 5: 283-296.

Ghahari, H., Huang, J. and Abd-rabou, S.A. 2011. Contribution to the Encarsia and Eretmocerus (Hymenoptera: Aphelinidae) species from the Arasbaran biosphere reserve and vicinity, northwestern Iran. Archives of Biological Science Belgrade, 63 (3): 867-878. 
Guerrieri, E. and Noyes, J.S. 2000. Revision of European species of genus Metaphycus Mercet (Hymenoptera: Chalcidoidea: Encyrtidae), parasitoids of scale insects. Systematic Entomology, 25: 147-222.

Habibi Badrabadi, S., Khayrandish, M. and Mohammadi-Khoramabadi, A. 2017. Faunistic survey and species diversity of parasitoid wasps of Pimpiliformes and Ichneumoniformes Groups (Hymenoptera: Ichneumonidae) in Yazd Province, Iran. Taxonomy and Biosystematics, 32: 4-20.

Hafez, M.B. 1988. Population fluctuations on parasites of California red scale, Aonidiella aurantii (Mask.) (Hem.: Diaspidae) in Alexandria. Journal of Applied Entomology, 106: 183-187.

Halawa, A.M., Nour EL-Deen, M.A., Attia, S.A. and EL-Sebaay, M.M. 2015. Population fluctuation of the white peach scale insect, Pseudaulacaspis pentagona (Targioni), associated parasitoid and predacious mites attacking peach trees at Dakahlia Governorate. Middle East Journal of Agriculture, 4(2): 250-259

Heraty, J. M., Woolley, J. B. and Polaszek, A. 2007. Catalog of the Encarsia of the world. http://cache. ucr.edu/ heraty/Encarsia.cat.pdf.

Invasive Species Compendium. 2016. From http:// www.cabi.org/isc/datasheet/45077.

Iranmanesh, M., Madjdzadeh, S.M. and Askari Hesni, M. 2017. Biodiversity of braconid fauna (Hym.: Ichneumonoidea: Braconidae) in Sirch region, Kerman province, Iran. Journal of Entomological Society of Iran, 37 (1): 1-13.

Jamalomidi, A., Hosseini, R., Sahragard, A. and Hajizadeh, J.A. 2012. Faunal study on armored scales (Hem: Diaspididae) parasitoids on citrus trees in eastern part of Guilan province. Proceedings of 20th Iranian Plant Protection Congress, University of Shiraz, 217.

Kyparissoudas, D.S. 1987. The occurrence of Encarsia perniciosi in areas of northern Greece as assessed by sex pheromone traps of its host Quadraspidiotus perniciosus. Entomologia Hellenica, 5: 7-12.

Lotfalizadeh, H., Zargaran, M.R. and Taghizadeh, M. 2014. Speceis diversity of Coccoidea parasitoids wasps (Hym.: Chalcidoidea) in the northern parts of East-Azarbaijan province, Iran. NorthWestern Journal of Zoology, 10(1): 60-66.

Magurran, A.E. 2004. Measuring biological diversity, Blackwell Publishing: Oxford, UK. 256 p.

Miller, D.R. and Davidson, J.A. 2005. Armored scale insect pests of trees and shrubs. Cornell University Press. pp. 437.
Modarres Awal, M. 1997. Family Aphelinidae (Hymenoptera), pp. 261-262. In: Modarres Awal, M. (ed.) List of agricultural pests and their natural enemies in Iran. Ferdowsi University Press, 429.

Natural History Museum. 2016. From http://www. nhm.ac.uk/our-science/data/chalcidoids/database/ detail.

Nee, S., Harvey P.H. and Cotgreave, P. 1992. Population persistence and the natural relationship between body size and abundance. In: Conservation of Biodiversity for Sustainable Development (Sandlund O.T., Hindar K. and Brown A.H.D. eds), p. 124-136. Scandinavian University Press, Oslo.

Pedata, P.A., Hunter, M.S. and Godfray, H.C.J. 1995. The population dynamics of the white peach scale and its parasitoids in a mulberry orchard in Campania, Italy. Bulletin of Entomological Research, 85: 531-539.

Peet, R.K. 1974. The measurements of species diversity. Annual Review of Ecology and Systematics, 5: 285-307.

Pielou, E.C. 1969. An introduction to mathematical ecology. New York: Wiley.cited in VIII + 286 S., 32 Abb., Preis 140s.

Simpson, E.H. 1949. Measurement of diversity. Nature 163, 688.cited in Magurran, A. E., 2004, Measuring biological diversity, Blackwell Publishing: Oxford, UK.256 p.

Shannon, C.E. and Weaver, W. 1949. The Mathematical Theory of Communication. University of IIlinois Press, Urbana.Weigmann, G. 1973. Zur Ökologie der Collembolen und Oribatiden im Grenzbereich Land-Meer (Collembola, Insecta Oribatei, Acari). Zeitschrift für wissenschaftliche Zoologie, 186: 295-391.

Smith, B. and Wilson, B. 1996. A consumer's guide to evenness indices. Gikos, 76 (1): 70-82.

Toorani, A.H. 2017. Study of population fluctuations of the white peach scale, Pseudaulacaspis pentagona Targioni-Tozzetti and its natural enemies in kiwi gardens of Ghaemshahr region. M.Sc. thesis in Agricultural Entomology, Faculty of Agriculture, Shahed University, Tehran, Iran, $117 \mathrm{p}$.

Weigmann, G. 1973. Zur Ökologie der Collembolen und Oribatiden im Grenzbereich Land-Meer (Collembola, Insecta - Oribatei, Acari). Zeitschrift für wissenschaftliche Zoologie, 186: 295-391.

Received: 28 July 2018; Accepted: 13 December 2018 


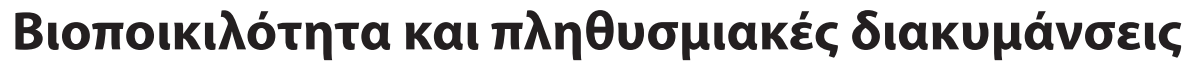

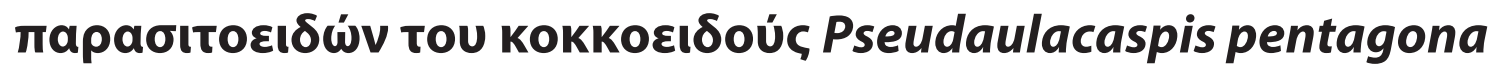

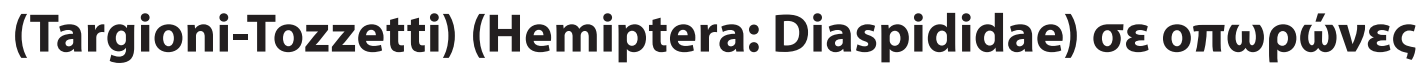

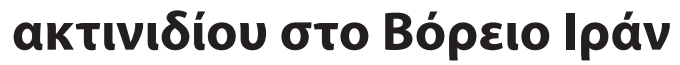

\author{
A.H. Toorani, H. Abbasipour kaı L. Dehghan-Dehnavi
}

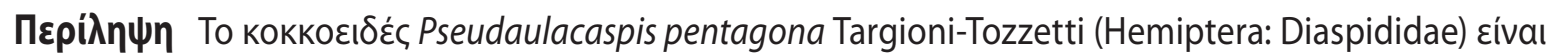

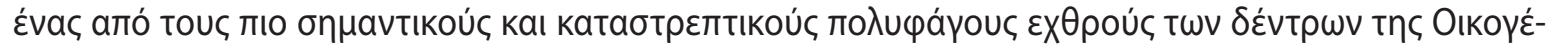

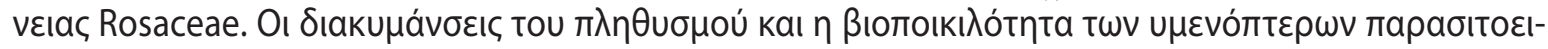

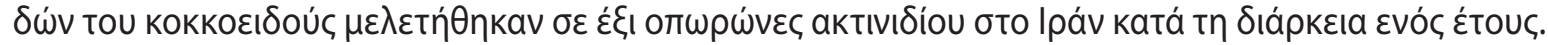

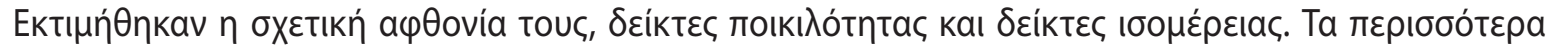

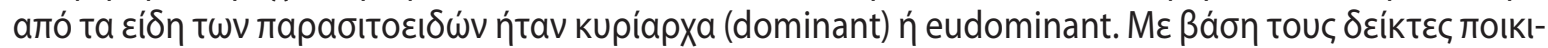

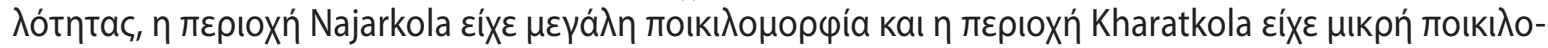

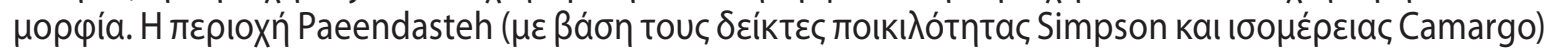

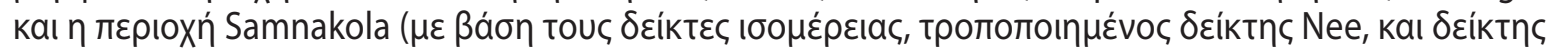

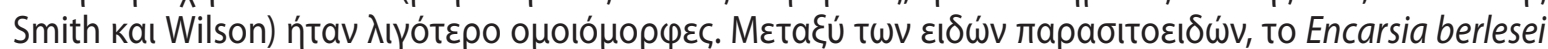
Howard (Hymenoptera: Aphelinidae) kal to Aphytis proclia Walker (Hymenoptera: Aphelinidae) cíxav

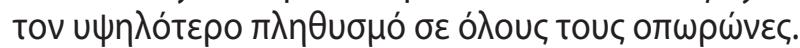

Hellenic Plant Protection Journal 12: 12-21, 2019 